\title{
Taxonomy, length-weight relationship, food and feeding habits of flower moon crab Matuta planipes Fabricius, 1798 from coastal waters of Gopalpur, Odisha, India
}

\author{
DURGA PRASAD BEHERA ${ }^{1}, \mathrm{~S}$. Y. TENJING ${ }^{2}$, ROCKTIM RAMEN DAS ${ }^{3}$, LAXMAN NAYAK $^{1}$ \\ AND D. MOHAPATRA \\ ${ }^{1}$ Department of Marine Sciences, Berhampur University, Berhampur - 760 007, Odisha, India \\ ${ }^{2}$ Department of Biosciences, Mangalore University, Mangalore - 574 199, Karnataka, India \\ ${ }^{3}$ Department of Ocean Studies and Marine Biology, Pondicherry University, Port Blair - 744112 \\ Andaman and Nicobar Islands, India \\ e-mail:durga.marine@gmail.com
}

\begin{abstract}
The relationship between carapace length (CL), carapace width (CW) and total weight (TW) in the flower moon crab Matuta planipes Fabricius, 1798 was studied and found to be $\mathrm{CL}=0.144+1.319 \mathrm{CW}$ and $\mathrm{CL}=0.356+1.273 \mathrm{CL}$ for males and females respectively. In case of the carapace width and total weight, the relationships were: $\mathrm{TW}=0.272 \mathrm{CW}^{3.011}$ and $\mathrm{TW}=0.474 \mathrm{CW}^{2.555}$ for males and females respectively. The relationships of carapace length and total weight were: $\mathrm{TW}=0.128 \mathrm{CL}^{2.917}$ for males and $\mathrm{TW}=0.184 \mathrm{CL}^{2.650}$ for females. A linear pattern was found between the relationship of $\mathrm{CL}$ and $\mathrm{CW}$ for $M$. planipes, whereas a curvilinear pattern was found between the relationship of $\mathrm{CL} / \mathrm{CW}$ and $\mathrm{TW}$ in the present study. It was also observed that $M$. planipes is an opportunistic omnivore, seaweed being the most dominant food item followed by crustaceans, seagrass, amphipods and miscellaneous matter.
\end{abstract}

Keywords: Allometric relationship, Distribution, Food and feeding habits, Gopalpur, Matuta planipes

\section{Introduction}

The western bank of the Bay of Bengal is enclosed by $2,019 \mathrm{~km}$ long coastline of the east coast of India (Vivekanandan and Krishnakumar, 2010), which consists of four maritime states, namely Tamil Nadu (TN), Andhra Pradesh (AP), Odisha and West Bengal (WB). The coastal and offshore waters of Odisha form a rich habitat for many macrofaunal organisms (Nagabhushanam, 1972). Decapod crabs are considered as a biologically and ecologically important group in marine ecosystem which play vital role in such biodiverse habitats. The information on Decapoda from Indian waters are available in plenty. However, along the east coast of India, several researchers have reported three species of crabs belonging to the genus Matuta from different regions, namely Hugli Malta Estuary in WB (Bhadra, 1995); Chilika Lake in Odisha (Sahoo et al., 2008); Godavari Estuary in AP (Roy and Bhadra, 2001) and Parangipettai waters in TN (Selvakumar and Khan, 1993).

The flower moon crab Matuta planipes Fabricius, 1798 belonging to the family Matutidae and subfamily Matutinae, is included in the super family Calappoidea due to presence of their ambulatory legs and chelipeds (Bellwood, 1996). Recently, information on M. planipes from the coastal region of south Odisha was reported by Rath and Roy (2010) from
Bahuda Estuary. Later they have also reported the same species from Banshadhara and Nagabali estuaries (Rath and Roy, 2011). Recently, this species was also reported from the subtidal zone of Gujarat by Jigneshkumar and Kauresh (2012). The present study is an attempt for taxonomic confirmation, evaluation of allometric relatioships as well as food and feeding habits of $M$. planipes along Gopalpur coastal waters in Odisha.

\section{Materials and methods}

The specimens of $M$. planipes (Fig. 1) were collected from trawl landings at Gopalpur Port $\left(19^{\circ} 15^{\prime} 33.73^{\prime \prime} \mathrm{N}\right.$; $84^{\circ} 54^{\prime} 42.84^{\prime \prime}$ ) during April to September 2013. A total of 320 specimens (160 males and 160 females) were examined. Standard measurements of the specimens such as carapace width (distance from the tip to tip of the last antero-lateral teeth) and carapace length (distance from the tip of the frontal teeth to the posterior end of the carapace) were taken using a digital vernier caliper. The total body weight was taken using an electronic balance at a precision of $0.01 \mathrm{~g}$. After taking morphometric measurements, specimens of carapace length ranging from 5-6 cm were dissected and the guts were collected and preserved in 4\% formaldehyde solution for gut content analysis. 
$\quad 83^{\circ} 0.0^{\prime} \mathrm{E} \quad 84^{\circ} 0.0^{\prime} \mathrm{E} \quad 85^{\circ} 0.0^{\prime} \mathrm{E} \quad 86^{\circ} 0.0^{\prime} \mathrm{E} \quad 87^{\circ} 0.0^{\prime} \mathrm{E} \quad 88^{\circ} 0.0^{\prime} \mathrm{E}$

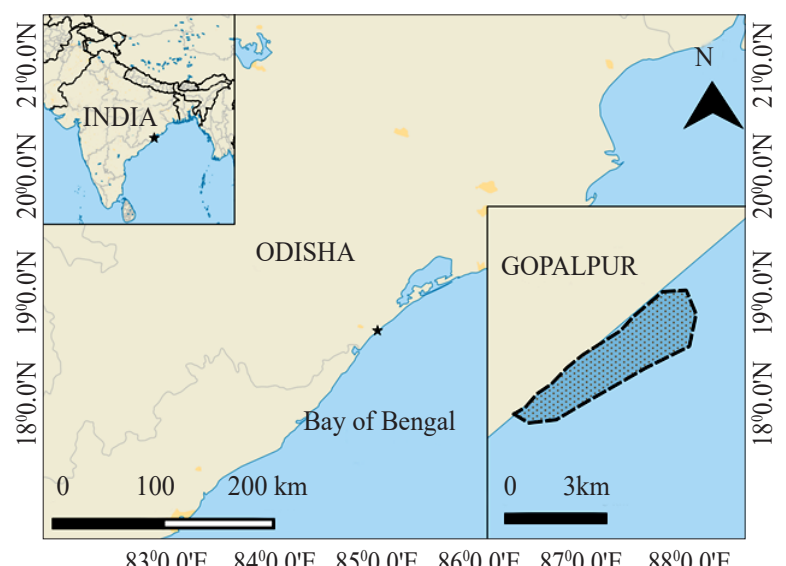

Fig. 1. Location of study area along Odisha coast

\section{Results and discussion}

Taxonomic hierarchy

Matuta planipes Fabricius, 1798

Phylum : Arthropoda

Class : Malacostraca

Order : Decapoda

Family : Matutidae

Genus : Matuta Weber 1795

1798 Matuta planipes: Fabricius, Ent. Syst. Suppl., 2: 369.

1896 Matuta victor: Alcock, J. Asiat. Soc. Bengal, 65:160.

1987 Matuta planipes: Anonymous, Mangrove Ecosystem of Sundarbans, 74 (Mangroves, Sundarbans, West Bengal).

1989 Matuta planipes: Mandal and Nandi, Fauna of Conservation Areas, 3 Zool. Surv. India: 26 (Mangroves, Sundarbans, West Bengal).

1994 Matuta planipes: Chaudhuri and Choudhuri, Mangroves of the Sundarbans, India,1: 232 (Mangroves, Sundarbans, West Bengal).

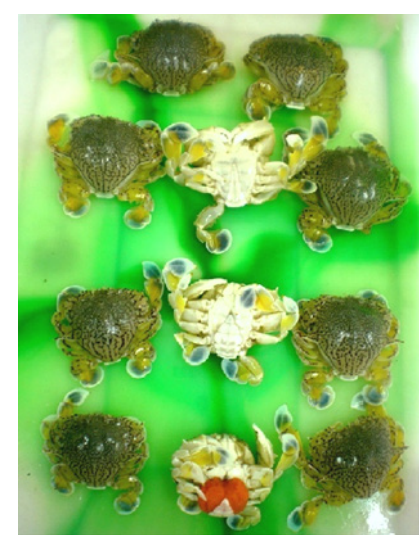

(a)

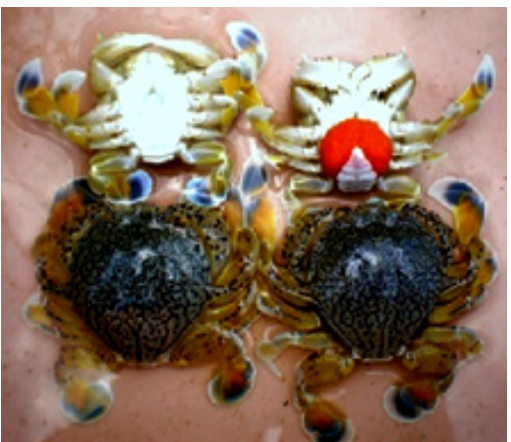

(b)
2000 Matuta planipes: Anonymous, Mangrove associated fauna. In: An ecological study of kachchh, mangroves and its associated fauna with reference to management and conservation, 31 (Mangrove; Munraj and Jakhau, Gulf of Kachchh, Gujarat).

2001 Matuta planipes: Dev Roy and Nandi, Bull. Nat. Inst. Ecol., 11:16 (Mangroves, Sundarbans, West Bengal and Andamans).

2004 Matula planipes: Venkataraman, Jeyabaskaran, Raghuram and Alfred, Rec. Zool. Surv. India, Occ. Paper No. 226:311 (Coral reef, Gulf of Mannar, Tamil Nadu, Andaman and Nicobar Islands).

2005 Matuta palmipes: Subba Rao and Sastry, An Overview, Conservation Area Series 23: Zool. Surv. India 51 (Marine National Park, Gulf of Kachchh, Gujarat) (incorrect spelling of 'planipes').

2008 Matuta planipes: Roy, M. K. D, An annotated checklist of Mangrove and Coral Reef inhabiting Brachyuran Crabs of India, India. Rec. Zool. Surv. India, Occ. Paper No., 289.

Material examined: 320 specimens from trawl landings at Gopalpur port

Diagnosis: Carapace subcircular, slightly convex, postero-lateral sides strongly convergent, with a $1 / 2$ inch horizontal epibranchial spine on either side. Tubercle at the angle of propodus where it touches the external angle of the merus indistinct. Carapace finely granular on epibranchial, post-gastric and cardiac regions. Of the six, the anterior two tubercles on the middle of carapace are obsolete; in adults the other four tubercles also less prominent. Antero-lateral sides of carapace crenulate. The postero-lateral sides of carapace form a finely beaded slightly raised ridge which ends at rear of the lateral spine. Front distinctly bilobed. Chelipeds equal and symmetrical. Carapace coloured with vermicular red line, forming spots or incomplete rings on the anterior portion of the carapace. Posterior region with narrow longitudinal loops (Fig. 2).

Fig. 2. (a) Male and Female M. planipes, (b) Ventral and dorsal sides of M. planipes, (c) Egg mass carried by female crab during spawning season 
Remarks: The presence of a tubercle at the angle where the propodus comes in contact with the distal lobule of the merus clearly distinguish the species from other species. M. planipes differs from M. victor (Fabricius, 1781) in having a single spine on external surface of male chela, straight lateral frontal lobes and carapace covered with reticulated loops as compared with the bispinose chela, rounded lobes and minutely spotted carapace of the latter. Generally smaller than M. lunaris which is now accepted as Ashtoret lunaris (Forskal, 1775). In M. planipes, a small granulate tubercle appears at lower proximal angle of palm and lower margin has a row of tubercles terminating at base of dactylus. In case of A. lunaris, lower margin has a row of triangular tubercles terminating at base of dactylus and a distalmost largest tubercle.

Colour: Carapace with reticulating brown lines forming small rings anteriorly and larger, elongate loops posteriorly.

Habitat: Occur in sandy beach between high and low tide marks to a depth of 10-15 m.

Distribution: West Bengal, Gujarat, Maharashtra (Roy, 2008); Karnataka (Dineshbabu et al., 2011); Kerala (Biju Kumar et al., 2007); Odisha (Deb, 1995); Andhra Pradesh (Roy and Nandi, 2008); Tamil Nadu (Krishnamoorthy, 2007); Lakshadweep (Varadharajan et al., 2012); Andaman and Nicobar Islands (Rao, 2010).

Elsewhere: Persian Gulf (Stephensen, 1945); Pakistan (Galil and Clark, 1995); Sri Lanka (Galil and Clark, 1995); Burma (Alcock, 1896), Sumatra-Aceh (de Man, 1898), Malaysia (Galil and Clark, 1995); Japan (Ortmann, 1892), Korea (Sakai, 1937), China (Shen, 1932), Taiwan (Lin, 1949); Vietnam (Galil and Clark, 1995); Singapore (Galil and Clark, 1995); Indonesia (Galil and Clark, 1995); New Guinea (Galil and Clark, 1995); Australia (Goeij et al., 2008).

In the present study, total number of specimens was 320, of which 160 were males and 160 females. The minimum and maximum sizes found in this study are given in Table 1. Carapace width of males ranged from 3.1 to $6.8 \mathrm{~mm}$ with a mean of $5.52 \mathrm{~mm}$ and that of females from 4.1 to $6.8 \mathrm{~mm}$, with mean of $5.49 \mathrm{~mm}$. Carapace length varied from 2.4 to $5.1 \mathrm{~mm}$ for males with a mean of $4.07 \mathrm{~mm}$ and for females, the range was 3.1-4.8 $\mathrm{mm}$ with a mean value of $4.03 \mathrm{~mm}$. Total weight varied from 3.1 to $35.0 \mathrm{~g}$ for males, whereas the range was 8.0 to $28.2 \mathrm{~g}$ for females. The equations of relationships between the variables for both sexes are given in Table 2. Monthly variations of length-width relationships of $M$. planipes are depicted in Fig. 3. It was found that linear pattern occurs in all the months. The relationships between carapace width $(\mathrm{CW})$-carapace length $(\mathrm{CL})$ for males and females were: $\mathrm{CL}=0.144+1.319 \mathrm{CW}$ and $\mathrm{CL}=0.356+1.273 \mathrm{CW}$

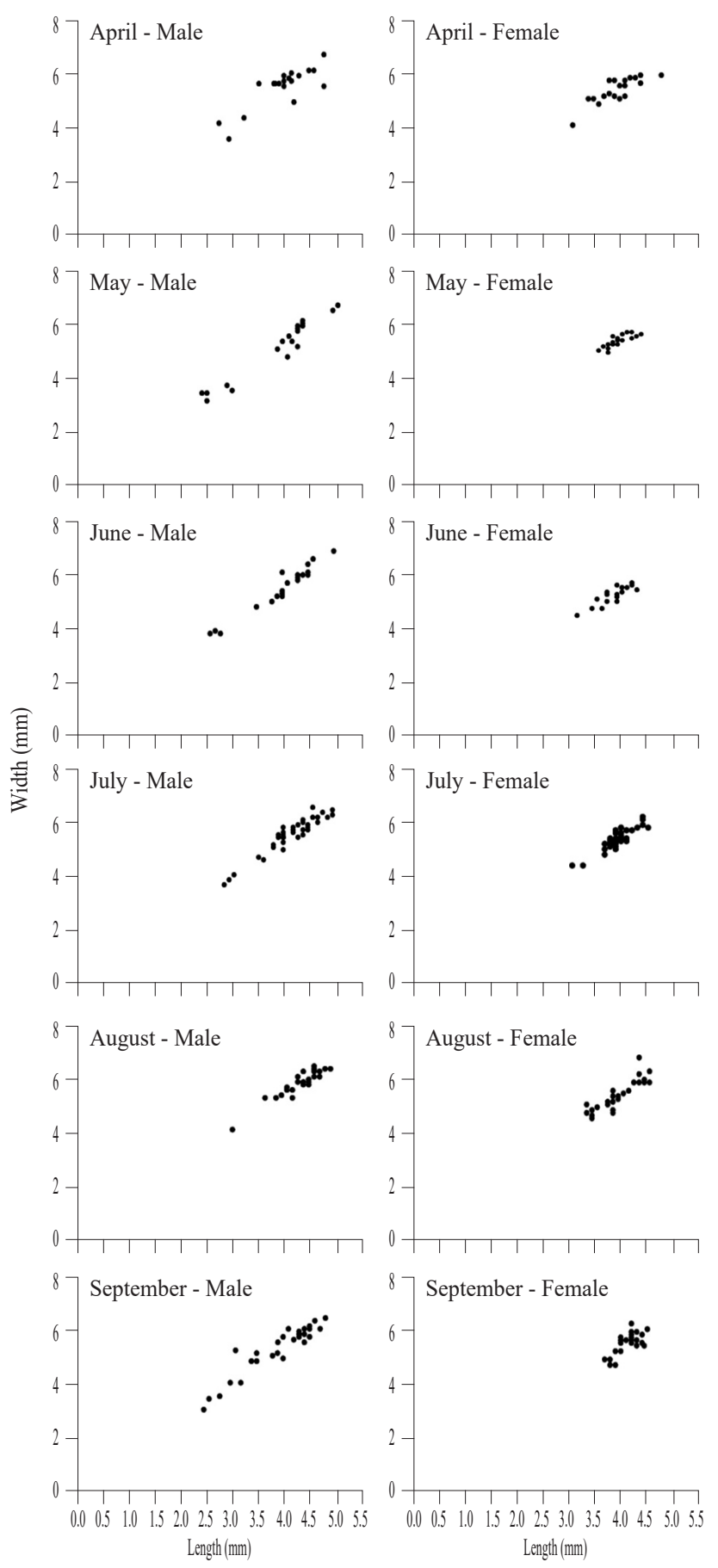

Fig. 3. Monthly length-width relationships of $M$. planipes

respectively. Overall length-width relationship also showed linear pattern (Fig. 4). The relationships between carapace width $(\mathrm{CW})$ - total weight (TW) for males and females were $\mathrm{TW}=0.272 \mathrm{CW}^{3.011}$ and $\mathrm{TW}=0.4742 \mathrm{CW}^{2.555}$ respectively. In case of carapace length $(\mathrm{CL})$ - total weight (TW) relationships, the equations for males and females for the entire dataset was of curvilinear pattern (Fig. 4). 
Table 1. Range and mean \pm SD (Standard Deviation) of body dimensions of male and females crabs

\begin{tabular}{|c|c|c|c|c|c|}
\hline \multicolumn{3}{|c|}{ Male } & \multicolumn{3}{|c|}{ Female } \\
\hline $\begin{array}{l}\text { Carapace length } \\
(\mathrm{mm})\end{array}$ & $\begin{array}{l}\text { Carapace width } \\
(\mathrm{mm})\end{array}$ & $\begin{array}{l}\text { Total weight } \\
(\mathrm{g})\end{array}$ & $\begin{array}{l}\text { Carapace length } \\
(\mathrm{mm})\end{array}$ & $\begin{array}{l}\text { Carapace width } \\
(\mathrm{mm})\end{array}$ & $\begin{array}{l}\text { Total weight } \\
\text { (g) }\end{array}$ \\
\hline $\begin{array}{l}2.4-5.1 \\
(4.07 \pm 0.60)\end{array}$ & $\begin{array}{l}3.1-6.8 \\
(5.52 \pm 0.84)\end{array}$ & $\begin{array}{l}3.1-35.0 \\
(20.05 \pm 7.62)\end{array}$ & $\begin{array}{l}3.1-4.8 \\
(4.03 \pm 0.32)\end{array}$ & $\begin{array}{l}4.1-6.8 \\
(5.49 \pm 0.42)\end{array}$ & $\begin{array}{l}8.0-28.2 \\
(17.14 \pm 4.31)\end{array}$ \\
\hline
\end{tabular}

Table 2. Allometric equations of body dimensions (carapace width $v s$ carapace length) and length/width $v s$ weight

\begin{tabular}{llllll}
\hline \multirow{2}{*}{ Parameters } & \multicolumn{2}{c}{ Male } & & \multicolumn{2}{c}{ Female } \\
\cline { 2 - 2 } \cline { 5 - 6 } & \multicolumn{2}{c}{ Regression equation } & & Regression equation \\
\hline Carapace width (CB)- Carapace length (CL) & $\mathrm{CL}=0.144+1.319 \mathrm{CB}$ & $r=0.956$ & & $\mathrm{CL}=0.356+1.273 \mathrm{CB}$ & $r=0.927$ \\
Carapace width (CB)- Total weight (TW) & $\mathrm{TW}=0.272 \mathrm{CB}^{3.011}$ & $r=0.941$ & & $\mathrm{TW}=0.4742 \mathrm{CB}^{2.555}$ & $r=0.777$ \\
Carapace length (CL)-Total weight (TW) & $\mathrm{TW}=0.128 \mathrm{CB}^{2.917}$ & $r=0.948$ & & $\mathrm{TW}=0.184 \mathrm{CB}^{2.650}$ & $r=0.810$ \\
\hline
\end{tabular}

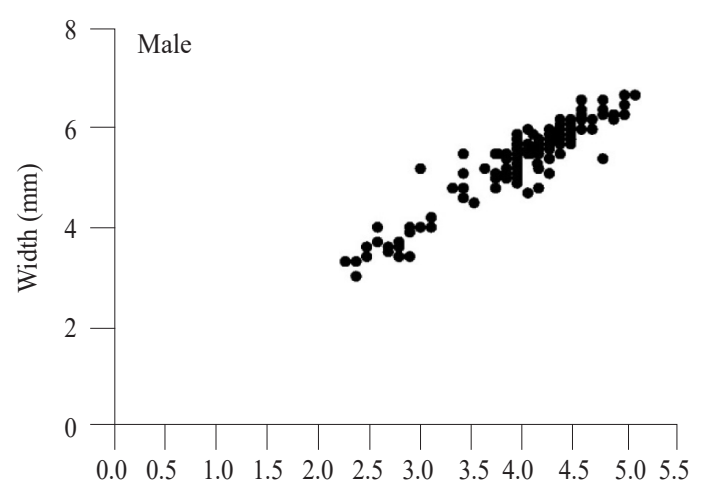

Length $(\mathrm{mm})$

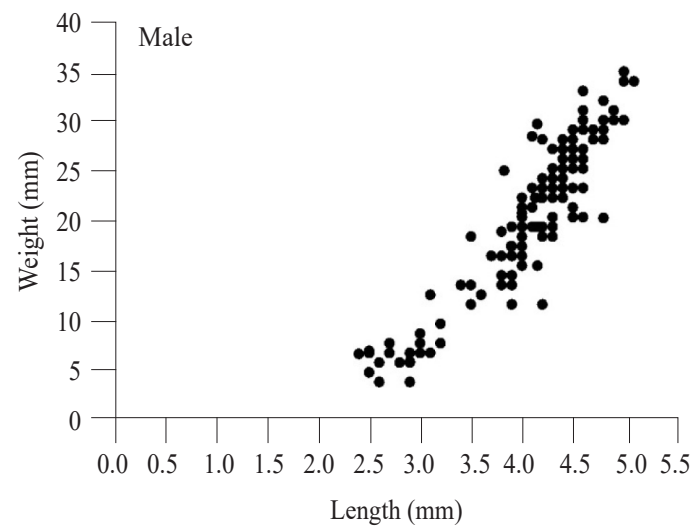

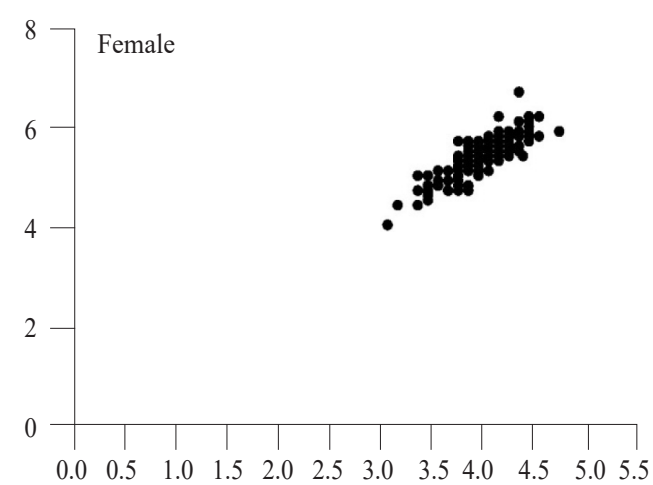

Length $(\mathrm{mm})$

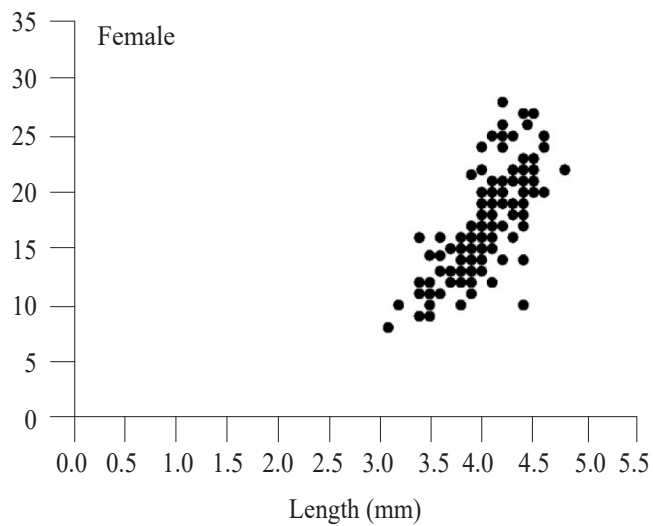

Fig. 4. Length-width and length-weight relationships of $M$. planipes for the entire study period

Scatter diagram for males and females of $M$. planipes was obtained by plotting length against width and length against weight (Fig. 3). It is clear from Fig. 4 that there is a good relationship between width and length. Coefficient of correlation $(r)$ obtained for width-length, width-weight and length-weight relationships of males were nearly equal to 1 indicating that the values were significant and hence, a high degree of positive correlation existed between width-length, width-weight and length-weight in these crabs. The width-weight and length-weight relationships were closely correlated for males with " $r$ " value almost near to 1 . For females, " $r$ " value was less than 0.9 for the width-weight and length-weight relationships. It showed that there is variation in these relationships. The curvilinear pattern observed for length-weight relationships of M. planipes (Fig. 4) is in agreement with the findings of Fatima (2003) who worked on M. planipes along Karachi coast of Pakistan. 
The exponential values $(b)$ of the width-length, widthweight and length-weight of male were 1.319, 3.011 and 2.917 respectively, whereas in female, the width-length, width-weight and length-weight were 1.273, 2.555 and 2.650 respectively. In the present study, the weights of individuals having same size varied. Perhaps it is due to food availability and spawning period. On the other hand, selectivity of the gears used by the various fleets was identified as a factor influencing the size structure.

Various species of crabs studied earlier viz., Scylla serrata (Hill, 1976; Joel and Raj, 1986; Prasad and Neelakantan, 1988); Callinectus sapidus (Laughlin, 1982); Scylla tranquebarica (Joel and Raj, 1986) and Thalamita crenata (Cannici et al., 1996) were found to consume mixed diets of polycheates, crustaceans, molluscs and fishes. Whenever food was found in stomach, it always consisted of a mixture of various groups. In the present study, seaweed contributed $31.71 \%$, mysid fragment $23.78 \%$, seagrass $20.12 \%$, amphipods $3.02 \%$ and miscellaneous matter formed $10.37 \%$ in the gut contents. The results of the present study indicated that $M$. planipes is an opportunistic omnivore. Williams (1982) stated that crabs are opportunistic omnivores with preferences for animal prey, but rarely feed on more mobile prey such as prawns and fish. Branco et al. (2010) also stated that crabs carry over the primitive behaviour of being opportunistic omnivores with a preference for animal food in conjunction with predatory propensity. Our results indicated that $M$. planipes is involved in biotic interactions and trophic relations.

\section{Acknowledgements}

The authors are thankful to P.G Department of Marine Sciences, Berhampur University for providing research facilities during the period of study. The first author acknowledges RGNF U.G.C fellowship (Grant number:F.14-2(SC)/2009SA Nov 2010, New Delhi, India) for financial support.

\section{References}

Alcock, A. 1896. Materials for a carcinological fauna of India. No. 2. The Brachyura Oxystoma. J. Asiat. Soc. Beng., 65: 134-296.

Bellwood, O. 1996. A phylogenetic study of the Calappidae H. Milne Edwards, 1837. (Crustacea: Brachyura) with a reappraisal status of the family. Zool. J. Linn. Soc., 118: $165-193$

Bhadra, S. 1995. Crustacea: Decapoda: Portunidae. Estuarine ecosystem series, Hugli Matla Estuary, Part 2. Zool. Surv. India, 2: 249-262.

Biju Kumar, A., Sushil Kumar, M., Raffi, S. M. and Khan, S. A. 2007. Diversity of brachyuran crabs associated with trawl bycatch in Kerala coast, India. Indian J. Fish., 54: 283-290.
Branco, J. O., Hillesheim, J. C., Fracasso, H. A. A., Christoffersen, M. L. and Evangelista, C. L. 2010. Bioecology of the ghost crab Ocypode quadrata (Fabricius, 1787) (Crustacea: Brachyura) compared with other intertidal crabs in the south-western Atlantic. J. Shellfish Res., 29: 503-512.

Canicci, S. F., Dahdoug-Guebas, F., Anyona, D. and Vannini, M. 1996. Natural diet and feeding habits of Thalamita crenata (Decapoda, Portunidae). J. Crustacean Biol., 1: 678-683.

Deb, M. 1995. Crustacea: Brachyura In: Wetland ecosystem series 1: Fauna of Chilka Lake. Zoological Survey of India, Calcutta, p. 345-366.

De Man, J. G. 1898. Berichtüber die von Herrn Schiffscapitan Storm zu Atjeh, an den westlichen Kusten von Malakka, Borneo und Celebes sowie in der Java-See gesammelten Decapoden und Stomatopoden. Theil 6. ZoologischeJahrbucher, Abteilung für Systematik, Geographie und Biologie der Thiere, 10: 677-708, pls 28-38.

Fatima, M. 2003. Length-weight study of two species of crabs Matuta planipes and Matuta lunarisfrom Karachi, Pakistan. Pak. J. Biol. Sci., 6: 397-398.

Galil, B. S. and Clark, P. F. 1995. A revision of the genus Matuta Weber, 1795 (Crustacea: Brachyura: Calappidae). Zool Verhandel., 294: 1-55.

Goeij, P., Lavaleye, M., Pearson, G. B. and Piersma, T. 2008. Seasonal changes in the macro-zoobenthos of Roebuck Bay: a 10 year study. NIOZ Koninklijk Nederlands Instituut voor Zeeonderzoek, Texel, 15 pp.

Hill, B. J. 1976. Natural food, fore-gut clearance rate and activity of the crab Scylla serrata. Mar. Biol., 34: 109-116.

Jigneshkumar, N. T. and Kauresh, D. V. 2012. Distribution and diversity of brachyuran crabs along the coastal region of Junagadh District, Gujarat. In: Prodeedings of National Seminar on Biodiversity and conservation of coastal and marine ecosystems of India, 13-15 September 2012, Ghatkopar, Mumbai, p. 6 -12.

Joel, D. R. and Raj, P. J. S. 1986. Food and feeding of the two species of Scylla (de Haan) Portunidae: Brachyura. J. Mar. Biol. Ass. India, 28: 178-183.

Krishnamoorthy, P. 2007. Brachyura. In: Fauna of Chennai Coast, Marine Ecosystem Series 1, Zoological Survey of India, Calcutta, p. 83-109.

Lin, C. C. 1949. A catalogue of Brachyurous Crustacea of Taiwan. Quart. J. Tai. Mus., 2(1): 10-33.

Laughlin, R. A. 1982. Feeding habits of the blue crab Callinectus sapidus Rathbun, in the Apachicola Estuary, Florida. Bull. Mar. Sci., 32: 807-822.

Nagabhushanam, A. K. 1972. Studies on the marine intertidal ecology of the Orissa coast. Proc. Indian Sci. Acad., 38B: $308-315$.

Ortmann, A. E. 1892. Die Decapoden-Krebse des Strassburger Museums, mitbesonderer Berücksichtigung der von Herrn Dr. Doderleinbei Japan und bei den Liu-Kiu-Inseln 
gesammelten und Z. im Strassburger Museum aufbewahrten Formen. Theil V. Die Abtheilungen Hippidea, Dromiidea und Oxystomata. Zoologischer Jahresbericht (Syst.), 6: 532-588, pl. 26.

Prasad, P. N. and Neelakantan, B. 1988. Food and feeding of the mud crab Scylla serrata (Forskal) (Decapoda, Portunidae) from Karwar waters. Indian J. Fish., 35: 164-170.

Rao, D. V. 2010. Field guide to coral and coral associates of Andaman and Nicobar Islands. Zoological Survey of India, Kolkata, 283 pp.

Rath, S. and Dev Roy, M. K. 2010. Crabs (Crustacea: Decapoda: Brachyura). Fauna of Vamsadhara and Nagavali Estuary, Estuarine Ecosystem Series. Zool. Surv. India, 6: 23-45.

Rath, S. and Roy, M. K. D. 2011. Crabs and prawns (Crustacea: Decapoda) of Bahuda estuary, Ganjam, Orissa. Rec. Zool. Surv. India, 111: 47-61.

Roy, M. K. D. 2008. An annotated checklist of mangrove and coral reef inhabiting brachyuran crabs of India. Zoological Survey of India, Kolkata, 212 pp.

Roy, M. K. D. and Bhadra, S. 2001. Brachyuran crabs (Crustacea: Decapoda: Brachyura). Fauna of Godavari Estuary, Estuarine Ecosystem Series. Zool. Surv. India, 4: 35-54.

Roy, M. K. D. and Nandi, N, C. 2008. Brachyuran biodiversity of some selected brackishwater of India. In: Sengupta, M. and Dalwani, R. (Eds.), Proceedings of Taal 2007: $12^{\text {th }}$ World Lake Conference, Jaipur, India, p. 496-499.
Sahoo, D., Panda, S., Guru, B. C. and Bhatta, K. S. 2008 A new record of Indo-Pacific crab Charybdis feriata (Linn., Brachyura: Portunidae) from Chilika Lagoon, Orissa, India. Bioscan, 2: 177-179.

Sakai, T. 1937. Studies on the crabs of Japan. II Oxystomata. Science Reports of the Tokyo Bunrika Daigaku, (B) 3(2): 67-192.

Selvakumar, S. and Khan, S. A. 1993. Grapsid and xanthid crabs of Parangipettai coast. Rec. Zool. Surv. India, 93: 329-354.

Shen, C. J. 1932. The brachyuran crustacea of North China. Zool. Sin., 9(1): i-x, 1-320, figs 1-171, pls 1-10.

Stephensen, K. 1945. The Brachyura of the Iranian Gulf with an appendix: The male pleopod of the Brachyura. In: Danish Scientific Investigations in Iran, Part 4. Copenhagen, Munksgaard, p. 57-237.

Varadharajan, D., Pushparajan, N. and Soundarapandian, P 2012. New record of portunid crabs from Pondicherry coast, south-east coast of India. Inter. J. Pharm. Biol. Arch., 3: $1255-1257$.

Vivekanandan, E. and Krishnakumar, P. K. 2010. Spatial and temporal differences in the coastal fisheries along the East coast of India. Indian J. Mar. Sci., 39: 380-387.

Williams, M. J. 1982. Natural food and feeding in the commercial sand crab Portunus pelagicus Linnaeus, (Crustacea: Decapoda: Portunidae) in Moreton Queensland. J. Exp. Mar. Biol. Ecol., 59: 165-176. 